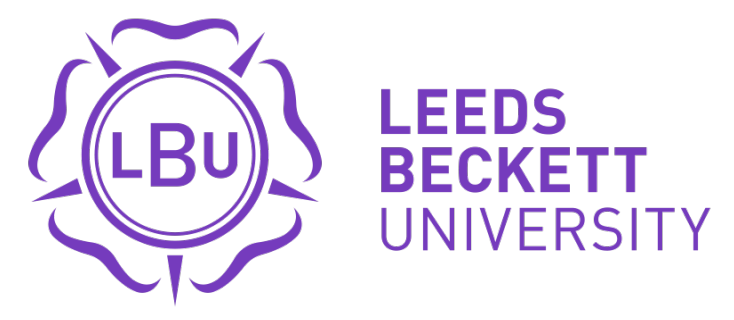

Citation:

Tate, $S$ and Gopinath, $G$ and Hemmings, $C$ and Dahl, $U$ and Kennedy-Macfoy, $M$ and Sunden, J and Galvez Munoz, L and Martinez Jimenez, L (2018) Femininity revisited - A round table. European Journal of Women's Studies, 25 (3). pp. 384-393. ISSN 1350-5068 DOI: https://doi.org/10.1177/1350506818774744

Link to Leeds Beckett Repository record:

https://eprints.leedsbeckett.ac.uk/id/eprint/5351/

Document Version:

Article (Accepted Version)

The aim of the Leeds Beckett Repository is to provide open access to our research, as required by funder policies and permitted by publishers and copyright law.

The Leeds Beckett repository holds a wide range of publications, each of which has been checked for copyright and the relevant embargo period has been applied by the Research Services team.

We operate on a standard take-down policy. If you are the author or publisher of an output and you would like it removed from the repository, please contact us and we will investigate on a case-by-case basis.

Each thesis in the repository has been cleared where necessary by the author for third party copyright. If you would like a thesis to be removed from the repository or believe there is an issue with copyright, please contact us on openaccess@leedsbeckett.ac.uk and we will investigate on a case-by-case basis. 


\section{Femininity revisited - A round table}

\section{Ulrika Dahl, madeleine kennedy-macfoy and Jenny Sundén}

One of our motivations for this special issue of European Journal of Women's Studies has been the paradox that femininity has posed for feminist theory. As we wrote in the introduction, it remains relatively under-scrutinised in the journal as well as, to some extent, more broadly in women's/gender studies: on the one hand, a central problem especially for (white) women, on the other, a seemingly undertheorised concept. Curiously, while we have deconstructed 'woman' as a unified subject and object of feminism, femininity itself seems to still need further reconfiguration. As an afterword to this issue, special issue editors Ulrika Dahl and Jenny Sundén have worked with Open Forum editor madeleine kennedy-macfoy on inviting a few scholars who have influenced our own work and whose work in turn has developed theoretical discussions around femininity to a virtual round table discussion. We thank Professor Lina Gálvez-Mu国ñoz and PhD researcher Laura Martínez-Jiménez, both scholars at Universidad Pablo de Olavide (Seville) and members of

\section{圆圆GED\&DO GEP\&DOObservatory; Gayatri Gopinath, Associate} Professor at the Department of Social and Cultural Analysis, New York University; Clare Hemmings, Professor of Gender Theory, London School of Economics; and Shirley Anne Tate, Professor of Race and Education at Leeds Beckett University for agreeing to share their thoughts here. 
First of all and by way of opening this discussion, we'd like to ask each of you what comes to mind when you think of the concept of femininity and how it works in your own research?

Lina Gálvez- In the deeply ambivalent scenario of

Muñoz and neoliberalised, postfeminist Western

Laura democracies, we think femininity must be

Martínezrevisited as a site of struggle. Hegemonic and

Jiménez: privileged senses of womanhood and the reinvigoration of inequalities tensely coexist with formal equality, a rising feminist awareness and women's survival strategies and their everyday embodiments and negotiations of femininity. As we feel it, critical studies about the diverse and intersectional ways of being women should explore feminine identities from/in their living conditions, as well as from/in the voices and experiences of women themselves. Thus feminist economics and feminist cultural studies cannot be given up to the degree that the meeting of both fields illuminates multidirectional links between economy, culture and subjectivity and the power relations that inform them. Besides, this conjunction also allows us to understand neoliberalism as a gendered, mobile governing project which uses economics for changing the heart and soul of 'women' as its "ideal subjects" insofar as its legitimation and reproduction depend to a great extent on "women" and their works. as its 'ideal 
subjects'insofar as neoliberal legitimation and reproduction depend to a great extent on 'women' and their work.

Shirley Femininity ... just the word introduces bioAnne Tate: political hierarchies when preceded by 'Black women's bodies and'. It is that 'and' that instantiates femininity's continuous removal from Black bodies whether as epistemological, performative, or social, whilst at the same time it makes us re-examine femininity itself. That 'and' makes us look at it hard. Why is it that when run through the filter of 'race', Black women's bodies are zones of the refusal of recognition of femininity? Why is it that the feminine still defaults to that colonial artefact the white woman's body? Here we have the 'good intentions' of a white/whitened femininity which still speaks for all women by making Black femininities an absence even within the presence of their emergence. Saying Black femininities is itself a resistance to the homogenising force of a femininity which would hobble all Black women together because of white supremacy's regimes of recognition. Of course, this goes beyond the politics of recognition and moves us towards thinking of what needs to be done to decolonise femininity itself as a white supremacist colonial artefact 
which continues to maintain white heteropatriarchal, cis-gendered domination.

Gayatri

Gopinath: $\quad$ in my first book, Impossible Desires: Queer

Diasporas and South Asian Public Cultures, where I was interested in developing a reading strategy that allows us to 'see' queer South Asian femininity. This is an embodied performance that is elided and indeed rendered an impossibility, both through a white, Euro-American-centric, homonormative vision, as well as through a dominant Indian nationalist vision. Both of these dominant modes of looking at South Asian femininity can only equate it with 'oppressed', 'passive', or 'exotic' Third World womanhood on the one hand, or with its availability to heterosexuality on the other hand. My goal in Impossible Desires was to disrupt these taken-for-granted epistemological frames through which South Asian femininity typically appears, and to instead enact a queer diasporic reading practice that allows us to 'see' the queerness of what may initially look like normative femininity - for instance, in representations of hyperbolic femininity by cis-gendered women in popular Indian cinema. The stakes of reading the queerness of femininity in this way 
is not to simply bring queer South Asian femininity into visibility for its own sake. Rather it is to argue that the elision of queer South Asian femininity is a constitutive absence within heteronormative Indian and homonormative gay imaginaries that allows a patriarchal, heteronormative Indian nationalist subject, and a white, homonormative First World subject, to be produced.

madeleine kennedymacfoy: when I think of the concept of femininity, I immediately think of its performative dimensions, and how that performativity is constituted through and in relation to race, class, sexuality and bodily ability. In research I conducted with adolescents in an all-girls' school some years ago, it quickly became apparent that the issues around citizenship and national identity on which the research was focused were inextricably bound to the students' performance of different types of femininities as a central part of their performance of gender. Of course, I mean performance here in Judith Butler's sense: as a continual and repetitive 'doing', so that femininity 'is performatively constituted by the very "expressions" which are said to be its results'. The 'diasporic citizenships' I observed 
and theorised were engendered and embodied through the performance of a range of racialised and classed femininities.

I join Shirley Anne Tate in her assertion above that femininity is continuously 'removed from Black women's bodies'. I'm also interested in how performances of femininity (and also of the anti- or non-feminine) mean that this continuous removal is also simultaneously continuously contested by the mere existence of Black women's and girls' bodies, and in different ways across time and space, the resistance in some of their performances of racialised and classed femininities.

Two contemporary examples of literal performances of Black women's femininity spring to mind, both of which have quickly gained cult status: the character of 'Cookie' in the Fox television series Empire (played by African-American actress Taraji P Henson), and the fictionalised Dora Milaje all-female warrior special force that protect the fictional Kingdom of Wakanda in the Marvel Comic Universe. There is not space here to do a full analysis, but I would argue that both Cookie and the Dora Milaje symbolise, in very different ways, a performative 'clap back' and unyielding resistance to the 'homogenising 
force' (as Professor Tate put it above) of a universalised white femininity.

Clare

Hemmings:
My work to date in this area has tended to focus on 'femme' subjectivities, practices or narratives. One of the reasons I remain interested in theorising femininity through consideration of femme desire is because I think this offers a useful way of thinking about trans-feminist solidarities while retaining a feminist critical position on the nature of oppression and the problematics of gender. I use the term 'femme' here as a way of trying to grapple with the particular ways in which gendered dynamics are important for me as part of desire; I'm less comfortable with 'femininity', in part because I'm not so sure what it means. As the editors indicated in their invitation, 'femininity' is both a central concern for feminism, but also woefully undertheorised except as lack or as patriarchal effect or dividend. For Hélène Cixous, for example, femininity is quite simply a phallocentric fantasy within which only 'masculinity' has content; it is the property of masculinity rather than its complement. In contemporary queer feminist and trans* theorising the challenge to gender binaries has of course been well under way for some 
time. I fully support trans ${ }^{*}$ critiques of gender binaries, trans* insistence on bodily integrity and have long worked in a queer feminist tradition concerned with the limits of gendered oppositions for all subjects (in terms of sexual, racial and classed hierarchies). But I have also done that from my particular position of femme subjectivity: a gendered location that is an important part of how I express and experience desire. This matters, I think, because it offers another way of critiquing heteronormative class and kinbound gender relations: not necessarily moving beyond or transitioning from one to another, but working with and in gender for pleasurable (and perhaps political) ends.

Ulrika

I share that interest in femme as you know and Dahl: agree that it may be particularly useful for grappling with gendered dynamics and desire, and in recent years it's clear that it has become one way in which trans desire is kept queer if you will. But could you say more about how you think femme does or does not get us out of the issues of white hegemony that seem to be haunting the concept of femininity?

Clare I don't think 'femme' gets anyone out of the Hemmings: problem of oppositional gendering and its 
colonial, heteronormative, age-bound

histories. As a white femme turning 50 (among other things I hope I am turning), the issue of privilege and accountability in gendered desire seems more important than ever. But consciously trying to occupy (or being drawn into occupying) femme as a site of desiring, a space of movement towards and away, might perhaps help de-naturalise femininity as a given, and thus as tethered to particular bodies and not others. 'Femme's' ambivalent reference to 'femininity' has always been appealing for queer subjects hoping to 'do something' with gender. For subjects who are loath to abandon gender's desiring dynamics even while critical of their capacity to reinforce femininity's association with whiteness, youth and heterosexuality, 'femme' can perhaps allow an opening to reflect on those associations.

Ulrika Dahl Yes, that resembles how the figure has worked and Jenny in and for us as well. So let's talk a little about Sundén: the idea of 'critical femininity studies'. For the past decade or more, critical masculinity studies has emerged as a distinct subfield of women's/gender studies. At the same time, there is nothing comparable around femininity. Why is that? Is such a field needed? What could 
be 'housed' there? Are there problems or limitations with such a knowledge formation?

Gayatri

Gopinath:
The goal of critical femininity studies is, as I see it, to create reading strategies supple enough to interpret and 'see' how femininity travels across differently gendered bodies and geographic locations, through various transnational cultural forms, and how different social formations such as class and race determine its meanings and contours. It is to think about the uses to which femininity is put within regimes of the dominant, as well as the ways in which it disrupts, troubles, and throws a wrench into the workings of the dominant, sometimes simultaneously. For instance, this past semester I taught a class with Lisa Duggan entitled 'Intersections of Race, Gender and Sexuality in a Global Frame'. In it, we spent a lot of time studying how normative regimes of white femininity in the form of maternalist politics have been central to North American, Australian and European white supremacist settler colonial and imperial projects throughout the globe. But we also looked at how hyperbolic performances of normative femininity, by activists such as Las Madres of the Plaza de Mayo during Argentina's 'Dirty War', also have the potential to undermine the 
workings of the state, even as they reinforce gender binaries. We studied how Black feminist scholarship in the US has theorised the tightly bound relation between what we can call toxic femininity and white supremacy in US history. But we also looked at the ways in which the toxicity of white femininity is neutralised by its radical re-appropriation and reworking by the everyday acts of imagination and creativity of queer and trans communities of colour. Thus to think about the relation between femininities is to consider how femininity intersects with various forms of domination, as well as how we might be able to theorise alliances between different forms of what we can call subaltern femininities: queer, femme, trans, femininities, for instance.

Clare That's one reason I am loath to theorise Hemmings: 'femininity' and 'masculinity' as correlates. For feminists, 'femininity' is precisely the demonised or even abjected gendered term, despite considerable efforts at reclamation. For Raewyn Connell, importantly, while masculinity can be 'hegemonic', ideal femininity is 'emphasised' rather than authoritative. What if we took Connell's understanding of 'emphasised femininity' in another direction - not only as the bedrock of 
white, bourgeois women's oppression but as a site of struggle. As theorists of 'femme' have argued from Joan Nestle onwards, to desire as a femme is to pull at femininity's necessary tie to heteronormativity and coloniality, to push at its association with docility and masculine fantasies of power and control. Might this open up the possibility of solidarity among a range of subjects who don't get to inhabit 'hegemonic masculinity' but also resist the limits of femininity when emphasised in only one direction?

Ulrika I'm sympathetic to this idea, and yet I wonder Dahl: about the themes brought up by Shirley Anne Tate and Gayatri Gopinath above, namely the ongoing hegemony of whiteness and the violent, racist colonialist histories tied to the concept itself. Would you say femme and queer movements do some of that reworking of toxic white femininity that Gayatri talks about (my research would certainly suggest it doesn't always) or what kinds of insights to theorising femininity more broadly does the gender queer spectrum bring in? And what happens to race here? My decade-long research on femmes made it abundantly clear that white femmes were working our and queering radically different traditions of femininity as well as of what it 
means to resist. And yet to my experience, white heterosexual middle class femininity remains the ideal that femme too deviates from/relates to.

madeleine kennedymacfoy:
Well, maybe we don't have (or need?) a critical femininity studies because the phenomena that such a sub-discipline would seek to understand, and arguably also disrupt, cannot be contained by theory! Maybe what we would look for in a critical femininity studies already exists in something we might think of as critical femininity praxis? Elements of which can be found in ... online explicitly intersectional feminist spaces, such as online magazine GalDem, or personified by musicians such as Janelle Monae.

I'm not suggesting that we don't need theory, not at all. I just wonder, as I often do, about the relationship between the (feminist) academe and (feminist) praxis; maybe, as Ulrika and Jenny stated at the beginning, femininity remains simultaneously central and undertheorised because its theorisation is always already the myriad ways in which it is embodied, lived, performed, conformed to, disrupted and resisted ...? 
Shirley We have to move the discussion away from a Anne Tate: femininity/femininities scholarship which does not see its normative centre as at all problematic. That is, a normative centre in which white scholars do not think of whiteness as a continuing racial project in which they are imbricated. Rather, lack of critique of the white norm of femininity is maintained because such scholars feel that 'race' only belongs to the bodies of those racialised others who claim the spaces of femininity. 'Race' as only properly belonging to Black bodies keeps whiteness as the norm and refuses the necessity for white criticality much as it refuses the necessity for thinking with, through and from the space of the racialised other which would enable the emergence of a Black decolonial feminist critique of femininity studies. Femininity studies should develop new centres as the contributors show but even those centres seem to shy away from the 'race' question. This shying away occurs even though 'race' and racism are integral to theoretical understandings, political practices and embodied performativities of femininities. If we are to adopt a Black decolonial feminist approach to femininity studies what would this mean in terms of critical, engaged scholarship? Such an analysis would be one that takes on board the coloniality of power, being, knowledge and affect as integral to the very construction of the category 'femininity'. A 
Blae Black decolonial feminist $k$ feminist-decolonial approach to femininity must construct new forms of becoming which are not focused on white Western (Wo)Man as a position from which Black women would know the world or be known by that world.

Lina Gálvez- Given our research interests and what we Muñoz and outlined above, we propose employable Laura femininity as a notion to understand the Martínez- mobile my(s)tification of the socioeconomic Jiménez: value of women's participation in the labour market, as well as of femininity itself, in unavoidable coalition with the multiplicity of works also performed by women. During the Great Recession, femininity has been considered an economic 'panacea' which has cushioned, as in a previous crisis, the aggressive social impact of the Great Recession and the austerity measures. In such circumstances, white, middle-class Western women's employment has been re-articulated from its original 1970s neoliberal sense as empowering and emancipating to a recessionary understanding as auxiliary and subsidiary in a media-constructed mancession context. Likewise, the preferred portrayal of femininity has transitioned from the modern, independent and entitled professional/career 
woman to the 'adaptive/coping' one and her hyper-feminised responsibilisation over survival.

Thus, employable femininity encapsulates the itinerant ambivalence of the neoliberal project with regard to women's lives, works and identities, as well as the differences among women themselves and their several (dis)affections with employment. In this sense, employable femininity aims at exposing such frictional ideas and experiences of being women mediated by the conditions of participation in the labour market in an ongoing neoliberal project that, as various authors have discussed, aggravates gender inequalities and generates even new discriminations, while favouring the transformation or breaking of some patriarchal chains.

Ulrika This is a very interesting concept and it certainly Dahl: brings something to the discussion of neoliberalism and its gendered dimensions. I am wondering though, in light of the other contributions here and quite extensive theorising within postcolonial, intersectional, queer and critical race scholarship, how this concept can be mobilised in relation to questions of race and racialisation, citizenship and migration? To what extent could we, for instance, think about what Helma Lutz and others have described in terms of the feminisation of migration, how this relates to intimate and sexual labour, to domestic care chains, and the overall growing racial 
segregation in the labour market with this terminology? And how, for you, do questions of sexuality and desire enter into this? Differently put, is the very concept of 'employable femininity' a 'universal one' or does it speak specifically to heterosexual white middle class women's situation in a historical setting we can call ‘the Great Recession'?

Lina Gálvez- Employable femininity is a mobile tool that Muñoz and allows looking at the in-relation experiences of Laura a diversity of women and at how their position Martínez- in the network of power relations conditions Jiménez: the value of their labour force and their own femininity. In any case, it would be dishonest to decouple the employability of white educated middle class women (affected by the increasing job insecurity and privatisation processes) from the global care chains, the feminisation of migration and the difficulties that women directly involved in these phenomena -most of whom are racialised and come from impoverished countries - must face in order to have access to both conventional citizenship (strongly associated to their employability) and to the new postfeminist and neoliberal citizenship of consumption. It would also be counterproductive to ignore the greater precarity and discrimination of racialised, 
disabled and/or LGTBIQ people/women who do not embody a profitable (neotraditional and/or fetishised) sense of femininity, which, in addition, is deeply tied to the exploitation of erotic capital (whether normative or exoticised) as a survival strategy. In brief, the perversion of employable femininity lies in disregarding the intersectionality of lived lives to universalise or isolate comparatively privileged experiences and to consider gender as the only or most important identity vector.

Ulrika Dahl Right. And perhaps thinking about employable and Jenny femininity in the ways that you articulate it Sundén: here offers one productive way forward for those who are dissatisfied with gender equality as an instrument and technology for assessing gendered power relations in a labour market and world so deeply shaped by inequalities, many of which are tied to heterosexism, racism, colonialism and imperialism. All of your contributions here point to the importance of both revisiting existing work on femininity and of doing further work that develops and reconsiders the concept of femininity in ways that show how it is not reducible to the gender trouble of white, middle class, heterosexual cisgendered women. What is clear to us from this conversation and the whole special issue is that 
the politics of femininity remains at the heart of a range of feminist work, in theory and practice. Thank you! 